\title{
Herbicidal efficacy of culture filtrates of Alternaria brassicicola and Alternaria gaisen against parthenium weed
}

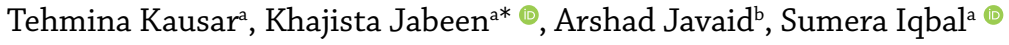

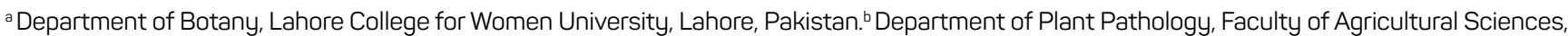 \\ University of the Punjab, Lahore, Pakistan.
}

\begin{abstract}
Background: Parthenium hysterophorus L. is one of the top ten worst weeds globally and is recorded in the global database of invasive species. Objective: The current study was aimed to evaluate the herbicidal potential of Alternaria brassicicola (Schwein.) Wiltshire and Alternaria gaisen Nagano. culture filtrates against a problematic weed P. hysterophorus.

Methods: $A$. brassicicola and $A$. gaisen culture filtrates were tested in vitro against the test weed. A. gaisen culture filtrates were found most effective against the test weed, and this test fungus was partitioned with various fractions viz. $n$-hexane, chloroform, ethyl acetate and $n$-butanol were isolated. In vitro bioactivity of these fractions were tested against $P$. hysterophorus. The most productive $n$-hexane fraction was subjected to GCMS analysis, and thirteen compounds were identified.

Results: A. gaisen original (100\%) and diluted (50\%) culture filtrates showed significant herbicidal activity against $P$. hysterophorus. However, culture filtrates of A. gaisen suppressed the germination, root and shoot growth of the
\end{abstract}

test weed to a greater extent compared with culture filtrates of $A$. brassicicola. Original culture filtrates of A. gaisen significantly reduced germination of P. hysterophorus by $88 \%$ as compared to diluted concentration by $56 \%$ in comparison with control. On the other hand, original and diluted culture filtrates of $A$. brassicicola reduced the germination of P. hysterophorus by $69 \%$ and $50 \%$, respectively, over control treatment. The $n$-hexane fraction was found more effective in suppressing the $P$. hysterophorus growth as compared to other fractions. Both $0.10 \%$ and $0.05 \%$ concentrations of $n$-hexane fraction significantly inhibited $P$. hysterophorus seedlings germination by $88 \%$ and $81 \%$, respectively. The $n$-hexane fraction was subjected to GC-MS analysis, and thirteen compounds were identified. Among these, ocimene (27.63\%); benzene 1-ethyl-3-methyl- (20.30\%) and $n$-hexadecanoic acid (10.27\%) were major compounds.

Conclusion: The present study concludes that $A$. gaisen culture filtrate has substantial herbicidal potential against $P$. hysterophorous.
Journal Information:

ISSN - 2675-9462

Website: http://awsjournal.org

Journal of the Brazilian Weed

Science Society

How to cite: Kausar T, Jabeen K, Javaid A, lqbal S. Herbicidal efficacy of culture filtrates of Alternorio brossicicolo and Alternorio gaisen against parthenium weed. Adv Weed Sci. 2022;40:e02224640. https://doi.org/10.51694/AdvWeedSci/2022;40:00002

Approved by:

Editor in Chief: Anderson Luis Nunes

Conflict of Interest: The authors declare that there is no conflict of interest regarding the publication of this manuscript.

Received: April 9, 2019

Approved: May 23, 2020

* Corresponding author: <khajista_1@hotmail.com>

\section{(c) (1)}

This is an open-access article distributed under the terms of the

Creative Commons Attribution License, which permits unrestricted use, distribution, and reproduction in any medium, provided that the original author and source are credited.

\section{Introduction}

Parthenium (Parthenium hysterophorus L.), family Asteraceae, is a devastating and dangerous weed of many economically important crops (Ray, Gour, 2012). It is among the top ten worst weeds worldwide and is included in the world catalogue of aggressive species (Callaway, Ridenour, 2004; Kapoor, 2012; Khan et al., 2020). In 1955, it was accidentally introduced through imported food grains in the subcontinent (Hassanein et al., 2008). It is also responsible for significant losses in the agricultural and forestry sector (Knox et al. 2006). P.hysterophorus also caused asthma, diarrhea and skin allergy in humans (Natukunda et al., 2020).

Use of commercial synthetic herbicides is considered as the most consistent and common technique for managing weeds. Another approach to control the weeds is to isolate natural herbicidal components from fungi culture filtrates (Zhang et al., 2010). Fungal metabolites can be used as a convenient biological pesticides tool (Cipriani et al., 2009; Sands, Pilgeram, 2009; Javaid et al., 2017; 2022).

The members of Deuteromycetes (fungi imperfecti), specifically Alternaria spp. have an extensive distribution in nature and act as saprophytes, endophytes, weak facultative parasites, and plant pathogens (Thomma, 2003). Some metabolites from Alternaria fungus are labelled as phytotoxins and mycotoxins for plants and animals, respectively (Duke, Dayan, 2011). Alternaria spp. metabolites have drawn the attention of many pharmacologists, chemists and plant pathologists in research programs due to the exhibition of various biological activities including herbicidal potential (Bräse et al., 2009; Tsuge et al., 2013; Bashir et al., 2018). However, studied regarding herbicidal activities of A. brassicicola and A. gaisen against parthenium weed are lacking. Therefore, this study was planned to explore the herbicidal efficacy of culture filtrates of A. brassicicola and A. gaisen for Parthenium weed biocontrol. 


\section{Materials and methods}

\subsection{Preparation of fungal culture filterate}

For the preparation of fungal culture filtrates, malt extract broth (2\%) $200 \mathrm{~mL}$ was autoclaved at $121^{\circ} \mathrm{C}$ for 15 minutes in $500 \mathrm{~mL}$ flasks and cool at room temperature. Five-millimetre discs of $A$. brassicicola and $A$. gaisen were added to these flasks and incubated for 15 days at $25^{\circ} \mathrm{C}$. The fungal cultures were filtered through a sterilised muslin cloth and sterilised Whattman No. 1 filter paper (Javaid et al., 2017). The filtered test fungal metabolites were centrifuged at $600 \mathrm{rpm}$ for 5 minutes and then refiltered with millipore filter paper.

\subsection{In vitro bioassay of fungal culture filterate}

In vitro assessment of fungal metabolites herbicidal activity against test, weed species was carried out following the protocol of Javaid and Ali (2011a; 2011b). Ninecentimetre pre-sterilized Petri plates were taken and lined with sterilised filter papers. Twenty surface-sterilised seeds of $P$. hysterophorus were set in all experimental Petri plates. Two millilitres of $100 \%$ and $50 \%$ concentrations of culture filtrates of $A$. brassicicola and $A$. gaisen were transferred to every Petri plate. The diluted concentration was prepared using sterilised distilled water in a suitable amount (Akbar, Javaid, 2013). In Petri plates of control treatment, two millilitres of distilled water were added. Each treatment was replicated three times. All the plates were incubated at $25{ }^{\circ} \mathrm{C}$ in an incubator with ten $\mathrm{h}$ daily light period for seven days. After that, data about germination, shoot and root length and seedling's fresh weight were noted.

\subsection{Fractionation of culture filtrates of $A$. gaisen}

A. gaisen culture filtrates were found very effective in reducing the in vitro growth of P. hysterophorus. Fifty millilitres of this fungal culture filtrate was taken for partitioning (Jabeen et al., 2014). Bioactive compounds in this filtrate were separated with several organic solvents like $n$-hexane, chloroform, ethyl acetate and $n$-butanol using a separating funnel. All the separated fractions were evaporated on a rotary evaporator which resulted in $0.02 \mathrm{~g} n$-hexane, $0.01 \mathrm{~g}$ chloroform, $0.12 \mathrm{~g}$ ethyl acetate and $0.14 \mathrm{~g} n$-butanol fraction.

\subsection{In vitro bioassay with isolated fractions of culture filtrates of $A$. gaisen}

The in vitro bioactivity of these four isolated fractions was studied. Two concentrations $(0.10 \% \& 0.05 \%)$ of each fraction were tested against $P$. hysterophorus. The experiment was conducted by the addition of $0.07 \mathrm{mg}$ and $0.03 \mathrm{mg}$ of all crude organic fractions and raised the final volume to $15 \mathrm{~mL}$. Control medium was without any extract. All the treatments were replicated thrice.

\subsection{Gas chromatography-mass spectrometry (GC-MS) analysis}

A. gaisen culture filtrates $n$-hexane fraction was analysed on GC-MS chromatograph (GC-MS-QP 2010) to separate bioactive compounds against $P$. hysterophorous. This $n$-hexane fraction was filtered through nylon membrane filters of $0.22 \mu \mathrm{m}$ pore size and $47 \mathrm{~mm}$ diameter by using filtration assembly. Chromatograph separated with the DB-5MS capillary column $(0.25 \mu \mathrm{m}$, $0.25 \mathrm{~mm}, 30 \mathrm{~m}$ ) was used to analyse the sample. Helium gas was used as a carrier gas and following program temperatures $40{ }^{\circ} \mathrm{C}$ for $5 \mathrm{~min}, 40-70{ }^{\circ} \mathrm{C}$ at $2{ }^{\circ} \mathrm{C} / \mathrm{min}$, $70{ }^{\circ} \mathrm{C}$ for $2 \mathrm{~min}, 70-120{ }^{\circ} \mathrm{C}$ at $3{ }^{\circ} \mathrm{C} / \mathrm{min}, 120-150{ }^{\circ} \mathrm{C}$ at $5{ }^{\circ} \mathrm{C} / \mathrm{min}, 150-220^{\circ} \mathrm{C}$ at $10{ }^{\circ} \mathrm{C} / \mathrm{min}$ and then $220^{\circ} \mathrm{C}$ for $2 \mathrm{~min}$ were applied. The temperatures of the detector and injector were $250{ }^{\circ} \mathrm{C}$ and $200{ }^{\circ} \mathrm{C}$, respectively. The mass detector conditions were: $70 \mathrm{ev}$ ionisation voltage, m/z 29-540 mass scanning range and $230{ }^{\circ} \mathrm{C}$ base temperature. GC peak areas were used to compare the percentage configuration of volatile constituents. Qualitative analysis was done on software NIST Library 2010 (Sureshkumar et al., 2012) based on mass spectra, comparison of indices and retention times with the analogous data in the previous literature.

\subsection{Statistical analysis}

All the obtained data were statistically analysed at 5\% level of significance by ANOVA (analysis of variance) and Duncan's Multiple Range Test (Steel, Torrie, 1980).

\section{Results and discussion}

In this study, the effect of culture filtrates of Alternaria spp. viz. A. gaisen and A. brassicicola were observed on germination and seedling growth of $P$. hysterophorus. Herbicidal effect of original (100\%) and diluted (50\%) culture filtrates of $A$. gaisen was more pronounced than culture filtrates of $A$. brassicicola. The original and diluted concentrations of culture filtrates of $A$. gaisen showed remarkable effect by inhibiting the germination of parthenium by $88 \%$ and $56 \%$, respectively, compared with control. Whereas original culture filtrate of $A$. brassicicola reduced P. hysterophorus germination by $69 \%$ and its diluted culture filtrate reduced germination by $50 \%$ of the tested weed specie as compared to the control treatment (Figure 1).

In case of other growth parameters also both concentrations of $A$. gaisen showed a significant reduction in shoot length, shoot fresh weight, root length, root fresh weight and the decrease was $84-99 \%, 65-99 \%$, $81-96 \%$ and $59-98 \%$ respectively (Figure 2A \& B). 


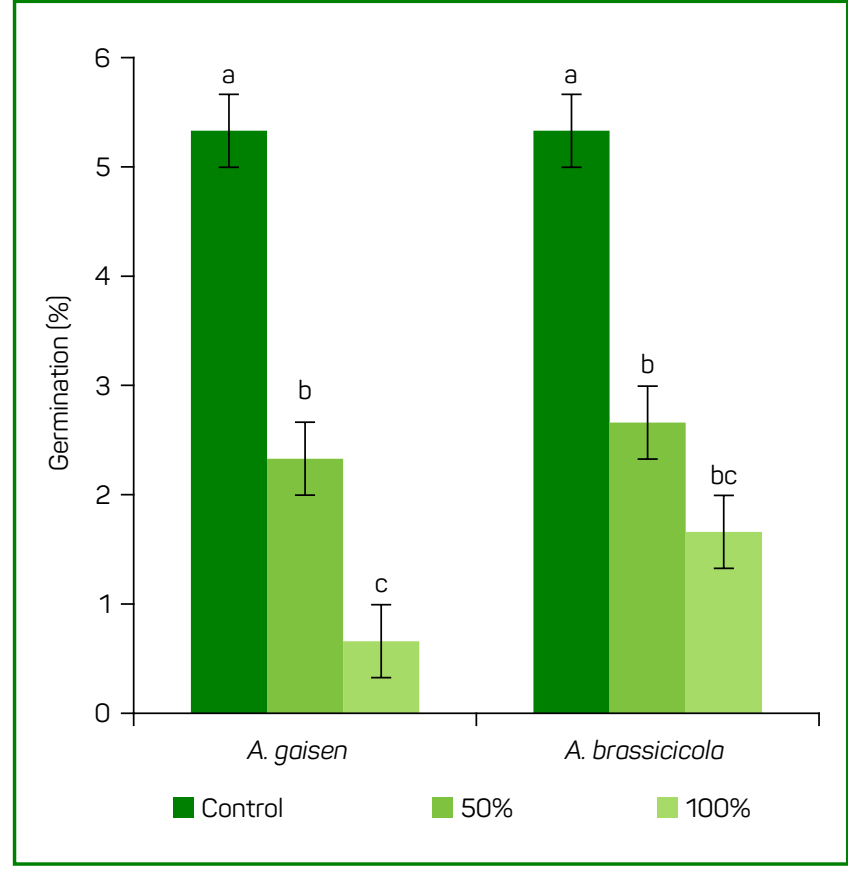

Figure 1 - Effect of $100 \%$ and $50 \%$ concentrations of $A$. gaisen and A. brossicicolo metabolites on germination of Parthenium seeds

On the other hand, culture filtrates of A. brassicicola reduced these growth parameters by $63-80 \%, 25-40 \%$, $62-73 \%$, 52-59\%, respectively (Figure 3A \& B). The metabolites of A. alternata, Fusarium solani, Drechslera rostrata, Trichoderma viride, T. pseudokoningii and $T$. harzianum significantly retarded the parthenium and other weed species seed germination (Javaid, Ali 2011a; 2011b). Culture filtrates of Cladosporium oxysporum, Macrophomina phaseolina and Fusarium equisetti also significantly inhibited parthenium's in vitro germination (Idrees, Javaid, 2008).

Results regarding the herbicidal activity of $n$-hexane, chloroform, ethyl acetate and $n$-butanol fractions of $A$. gaisen culture filtrates against the test weed species $P$. hysterophorous are illustrated in (Figure 4). Data obtained after a seven-day incubation period revealed that the $n$-hexane fraction displayed the best herbicidal activity compared to other tested organic fractions. The applied concentrations of $n$-hexane fraction viz. $0.10 \%$ and $0.05 \%$ significantly inhibited the germination of test weed by $88 \%$ and $81 \%$, respectively. This variable herbicidal expression of the applied fractions of fungal metabolites might cause the solubility of various compounds in different organic solvents (Zonno et al., 2008). The herbicidal efficacy of Alternaria species could be owed to the production of some secondary metabolites, some of which are powerful mycotoxins (Thomma, 2003). Like A. alternata produced a phytotoxin AAL-toxin which has the potential of suppressing the growth of numerous weeds (Abbas et al., 1995).

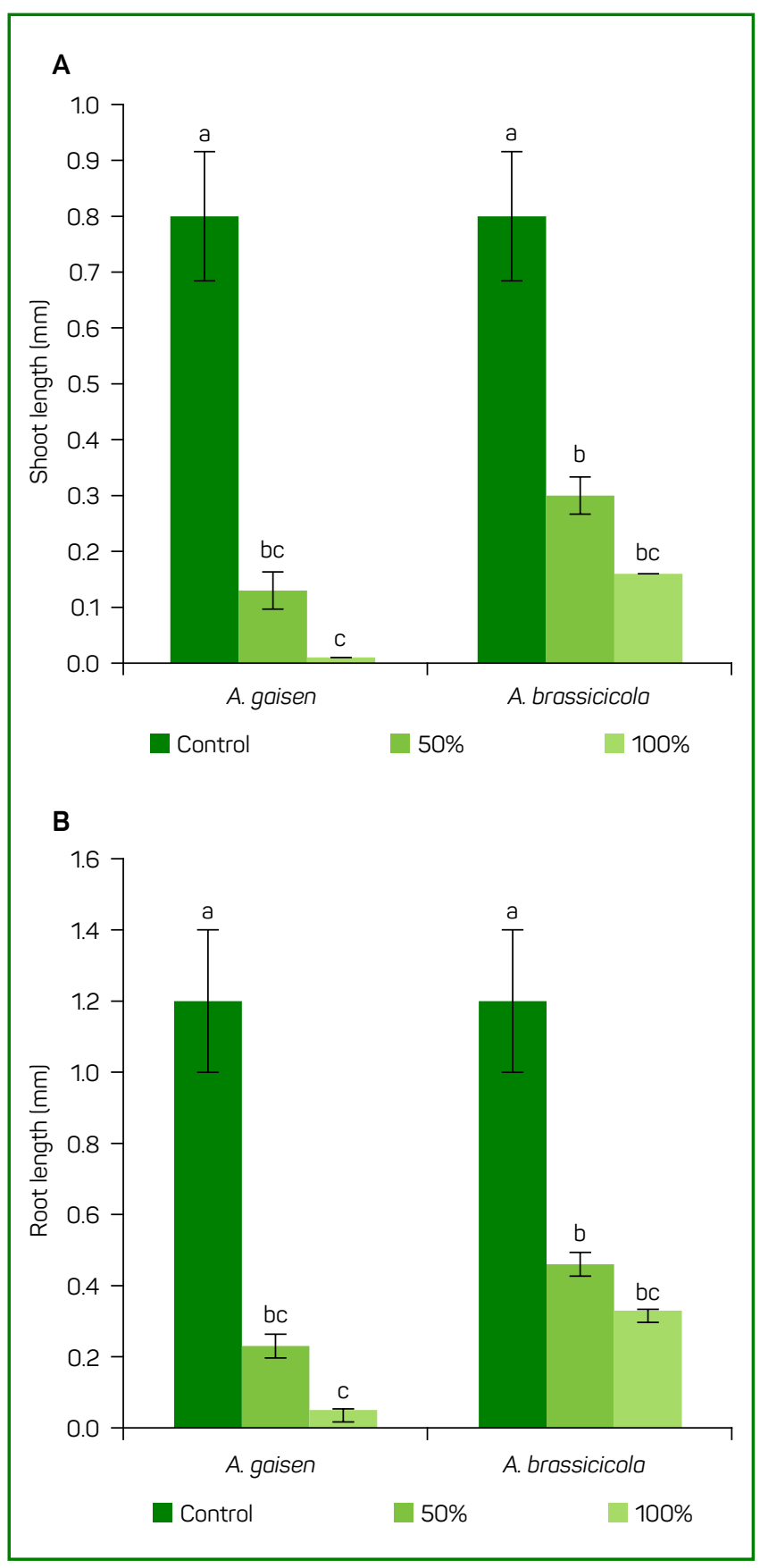

Figure 2 A, B - Effect of 100\% and 50\% concentrations of $A$. gaisen and $A$. brossicicola metabolites on root \& shoot length of Parthenium seeds

Thirteen compounds were identified in the GC-MS analysis of $n$-hexane fraction of $A$. gaisen culture filtrates (Table 1). The compounds ocimene (27.6\%), benzene 1-ethyl-3-methyl- (20.3\%) and $n$-hexadecanoic acid (10.22\%) were identified as major constituents. Other identified compounds were 3-trifluoroacetoxypentadecane (6.4\%), trichloroacetic acid 2-tetradecyl ester (6.40\%), Z,Z,Z-,4,6,9-nonadecatriene (4.4\%), 2,2,6-trimethylbicyclo[4.1.0]hept-1-yl)-methanol (4.1\%), 2-nitrohept- 


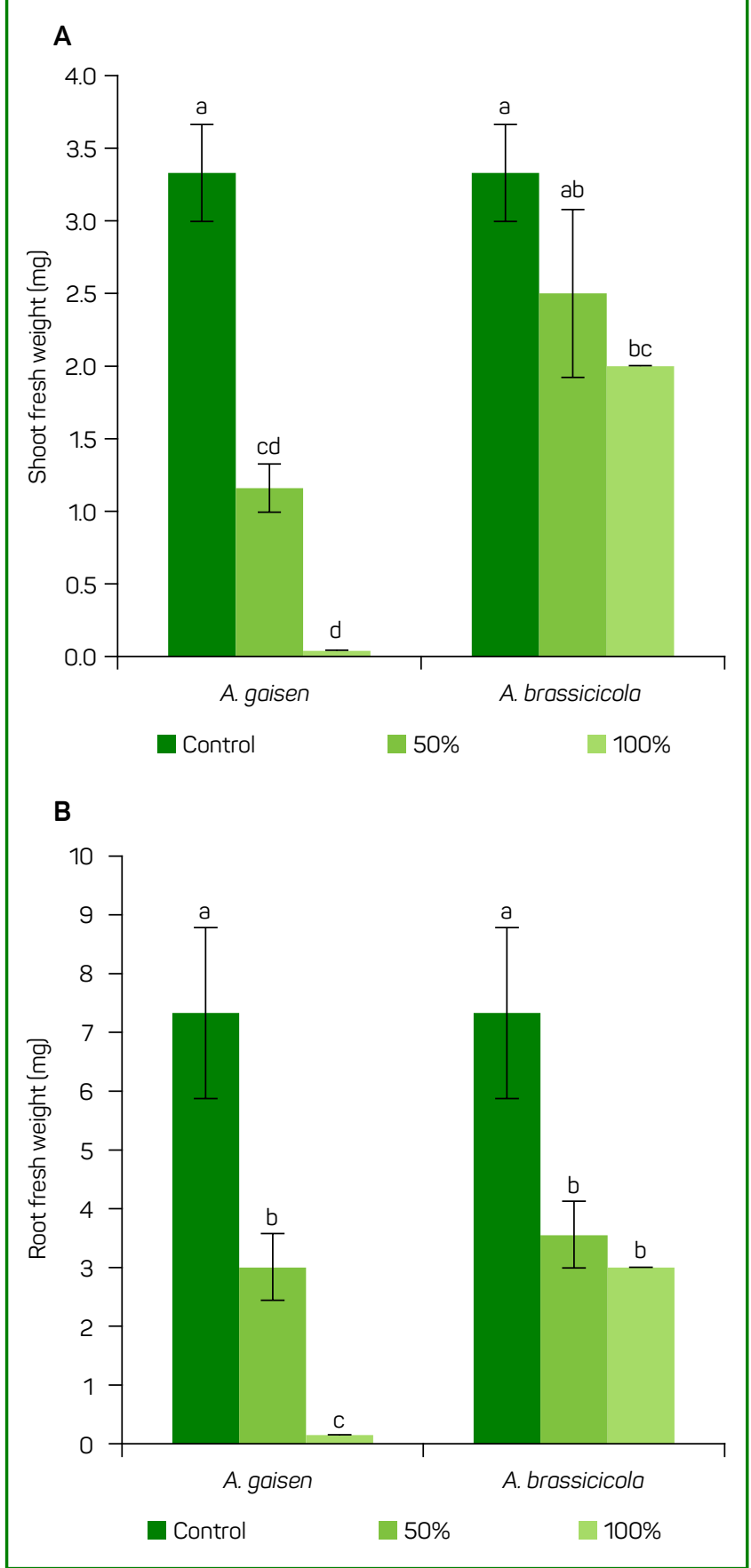

Figure 3 A, B - Effect of $100 \%$ and $50 \%$ concentrations of $A$. gaisen and A. brassicicola metabolites on root \& shoot fresh weight of Parthenium seeds

2-en-1-on (4.1\%), Z,Z,Z-1,4,6,9-nonadecatetraene (4.0\%), oleic acid (3.2\%), 3-trifluoroacetoxytetradecane (3.2\%), nonadecane (3.1\%) and 3,7,11,15-tetramethyl-2hexadecene-1-ol (2.7\%). Javaid et al. (2019) also identified ten bioactive compounds from $n$-hexane fraction of $A$. japonica. Ocimene a monoterpene compound is well known for its antimicrobial activity. The antimicrobial effects of ocimene were also tested on economically

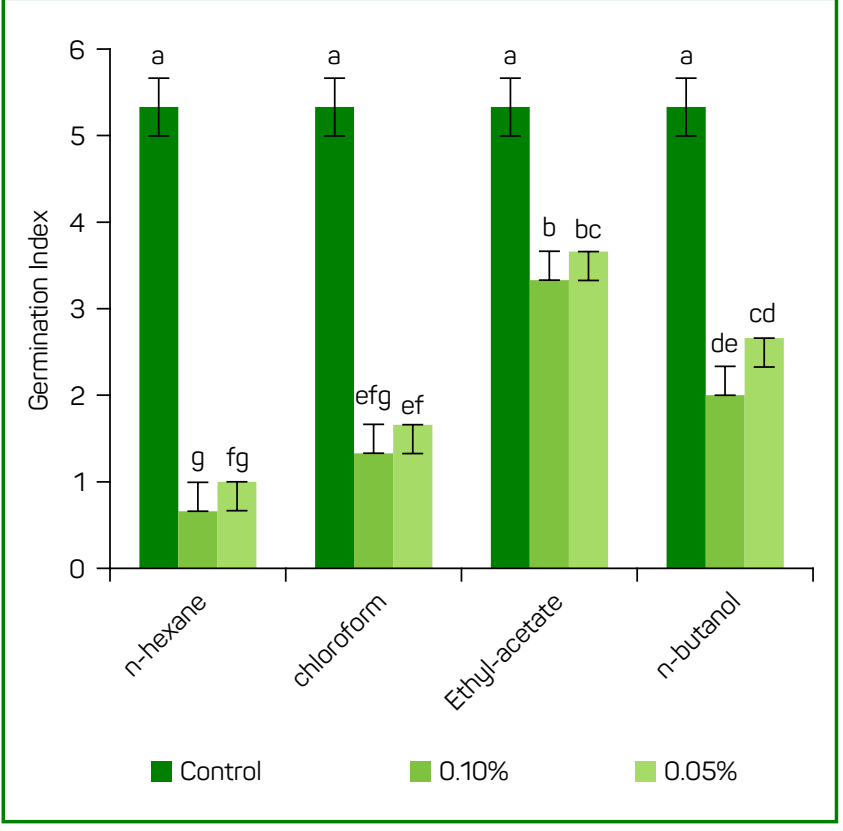

Figure 4 - Result of various organic fractions concentrations of $A$. gaisen metabolite's on in vitro growth of $P$. hysterophorus

important microbes, and promising results were found (Pirbalouti et al., 2016; Mahdian et al., 2017). The second major isolated compound was benzene 1-ethyl-3-methylwhich is an aromatic hydrocarbon). This compound possesses substantial antifungal and antibacterial property (Vukovic et al., 2007). $n$-hexadecanoic acid a saturated fatty acid was also found in the GC-MS analysis in the present study. $n$-hexadecanoic acid was isolated from many plants and hold herbicidal and fungi toxic effects (Kordali et al., 2009; Shirani et al., 2017). 3-trifluoroacetoxypentadecane a bioactive compound produced fungi-static effects against Aspergillus terreus. Oleic acid, an unsaturated fatty acid identified in the present study, was found to establish resistance in plants and microorganism and be used as a pesticide (Pohl et al., 2011). The substantial herbicidal effects of 3,7,11,15-tetramethyl-2-hexadecen1-ol isolated from Mikania micrantha were also deliberated by $\mathrm{Ni}$ et al. (2007).

\section{Conclusion}

This syudy conclude that the herbicidal potential of $A$. gaisen against $P$. hysterophorus could be attributed to the presence of many significant compounds present in this tested fungus. Furthermore, A. gaisen can effectively be used as an alternative to chemical herbicides to manage this problematic weed $P$. hysterophorus.

\section{Authors' contributions}

All authors have read and agreed to the published version of the manuscript. $\mathrm{KJ}$, and $\mathrm{AJ}$ : conceptualization. 


\begin{tabular}{|c|c|c|c|c|c|}
\hline $\begin{array}{l}\text { Sr. } \\
\#\end{array}$ & R. Time & $\begin{array}{c}\text { Compound } \\
\text { Name }\end{array}$ & $\begin{array}{c}\text { Molecular } \\
\text { Formula }\end{array}$ & $\begin{array}{c}\text { Molecular } \\
\text { Weight }\end{array}$ & $\begin{array}{c}\text { Peak } \\
\text { Area (\%) }\end{array}$ \\
\hline 1 & 5.223 & Benzene 1-ethyl-3-methyl- & $\mathrm{C}_{9} \mathrm{H}_{12}$ & 120 & 20.304 \\
\hline 2 & 5.81 & Ocimene & $\mathrm{C}_{10} \mathrm{H}_{16}$ & 136 & 27.632 \\
\hline 3 & 7.651 & Trichloroacetic acid, 2-tetradecyl ester & $\mathrm{C}_{16} \mathrm{H}_{29} \mathrm{Cl}_{3} \mathrm{O}_{2}$ & 360 & 6.404 \\
\hline 4 & 8.909 & 2-Nitrohept-2-en-1-ol & $\mathrm{C}_{7} \mathrm{H}_{13} \mathrm{NO}_{3}$ & 159 & 4.092 \\
\hline 5 & 10.345 & 3-Trifluoroacetoxytetradecane & $\mathrm{C}_{16} \mathrm{H}_{29} \mathrm{~F}_{3} \mathrm{O}_{2}$ & 310 & 3.208 \\
\hline 6 & 12.132 & 2,2,6-Trimethyl-bicyclo[4.1.0]hept-1-yl)-methanol & $\mathrm{C}_{11} \mathrm{H}_{200}$ & 168 & 4.148 \\
\hline 7 & 12.831 & 3-Trifluoroacetoxypentadecane & $\mathrm{C}_{17} \mathrm{H}_{31} \mathrm{~F}_{3} \mathrm{O}_{2}$ & 324 & 6.427 \\
\hline 8 & 13.32 & Z,Z,Z-,4,6,9-Nonadecatriene & $\mathrm{C}_{19} \mathrm{H}_{34}$ & 262 & 4.397 \\
\hline 9 & 14.295 & Z,Z,Z-1,4,6,9-Nonadecatetraene & $\mathrm{C}_{19} \mathrm{H}_{32}$ & 260 & 4.004 \\
\hline 10 & 15.626 & 3,7,11,15-tetramethyl-2-hexadecen-1-ol & $\mathrm{C}_{20} \mathrm{H}_{400}$ & 297 & 2.742 \\
\hline 11 & 17.813 & n-hexadecanoic acid & $\mathrm{C}_{16} \mathrm{H}_{32} \mathrm{O}_{2}$ & 256 & 10.277 \\
\hline 12 & 20.084 & Oleic acid & $\mathrm{C}_{18} \mathrm{H}_{34} \mathrm{O}_{2}$ & 282 & 3.246 \\
\hline 13 & 21.422 & Nonadecane & $\mathrm{C}_{19} \mathrm{H}_{40}$ & 269 & 3.119 \\
\hline
\end{tabular}

TK: methodology, investigation, data curation, writing, original draft preparation. KJ, TK, AJ, and SI: software, formal analysis. KJ, AJ and SI: validation. KJ, and TK: writing-review and editing.

\section{Acknowledgements}

The authors are thankful to the Botany Department, Lahore College for Women University, Lahore, Pakistan, and its support in this study is acknowledged.

\section{References}

Abbas HK, Tanaka T, Duke S, Boyette C. Susceptibility of various crop and weed species to AAL-toxin, a natural herbicide. Weed Technol. 1995;9(1):125-30. Available from: https://doi.org/10.1017/ s0890037X0002306X

Akbar M, Javaid A. Prospects of using fungal metabolites for the management of Rumex dentotus, a problematic weed of wheat. Int J Agric Biol. 2013;15(6):1277-82

Bashir U, Khan A, Javaid A. Herbicidal activity of Aspergillus niger metabolites against parthenium weed. Planta Daninha. 2018;36:1-9. Available from: https://doi.org/10.1590/S0100-83582018360100025

Bräse S, Encinas A, Keck J, Nising CF. Chemistry and biology of mycotoxins and related fungal metabolites. Chem Rev. 2009;109(9):390390. Available from: https://doi.org/10.1021/cr050001f

Callaway RM, Ridenour MW, Novel weapons: invasive success and the evolution of increased competitive ability. Front Ecol Environ. 2004;2(8):436-43. Available from: https://doi. org/10.1890/1540-9295(2004)002[0436:NWISAT]2.0.CO;2

Cipriani MG, Stea G, Moretti A, Altomare C, Mulè G, Vurro M. Development of a PCR-based assay for the detection of Fusorium oxysporum strain FT2, a potential mycoherbicide of Orobanche romoso. Biol Control. 2009;50(1):78-84. Available from: https://doi.org/10.1016/j.biocontrol.2009.03.005
Duke SO, Dayan EF. Modes of action of microbially-produced phytotoxins. Toxins. 2011;3(8):1038-64. Available from: https://doi.org/10.3390/toxins3081038

Hassanein N, Abou Zeid M, Youssef K, Mahmoud D. Efficacy of leaf extracts of neem (Azodirachto indica) and chinaberry (Melia azedorach) against early blight and wilt diseases of tomato. Austr J Basic Appl Sci. 2008;2(3):763-72.

Idrees $H$, Javaid A. Screening of some pathogenic fungi for their herbicidal potential against parthenium weed. Pak J Phytopathol. 2008:20(1):150-5.

Jabeen K, Zubairi T, Iqbal S. Control of Botrytis cinereo (Grey mould disease) by methanolic extract of Pongamia pinnato $L$. Mitt Klostern. 2014;64(3):105-13.

Javaid A, Ali S. Alternative management of a problematic weed of wheat Aveno fatuo L. by metabolites of Trichoderma. Chil J Agri Res. 2011a;71(2):205-11. Available from: https://doi.org/10.4067/S071858392011000200004

Javaid A, Ali S. Herbicidal activity of culture filtrates of Trichodermo spp. against two problematic weeds of wheat. Nat Prod Res. 2011b;25(7):730-40. Available from: https://doi.org/10.1080/1478641 9.2010 .528757 
Javaid A, Khan IH, Jabeen K, Bashir U. Evaluation of mycochemical profile of Alternario japonica through GC-MS analysis. Pak J Phytopathol. 2019;31(2):171-5. Available from: https://doi.org/10.33866/phytopathol.031.02.0537

Javaid A, Mubeen T, Bashir $U$, Shoaib A. Management of parthenium weed using metabolites of Alternario japonica. Planta Daninha. 2017;35:1-6. Available from: https://doi.org/10.1590/ S0100-83582017350100016

Javaid A, Jabeen $T$, Khan $\mathrm{H}$, Jabeen $\mathrm{K}$, Akbar M. Herbicidal potential of Alternario citri Ellis and Pierce metabolites against Parthenium hysterophorus L. Allelopathy J. 2022;55(1):25-34. Available from: https://doi.org/10.26651/allelo.j/2022-55-1-1368

Kapoor R. Awareness related survey of an invasive alien weed, Porthenium hysterophorus L. in Gautam Budh Nagar district, Uttar Pradesh, India. J Agric Technol. 2012;8(3):1129-40.

Khan N, Bibi K, Ullah R. Distribution pattern and ecological determinants of an invasive plant Parthenium hysterophorus L., in Malakand division of Pakistan. J Mt Sci. 2020;17:1670-83. Available from: https://doi.org/10.1007/s11629-019-5932-7

Knox J, Dass A, Thomas M, Paul MS. Management of Parthenium hysterophorus L. through Atrazine with Cossio unifloro extract. Ann Plant Protect Sci. 2006;14(2):459-61.

Kordali S, Cakir A, Akcin TA, Mete E, Akcin A, Aydin T et al. Antifungal and herbicidal properties of essential oils and $n$-hexane extracts of Achilleo gypsicolo Hub-Mor. and Achilleo biebersteinii Afan. (Asteraceae). Ind Crops Prod. 2009;29(2/3):562-70. Available from: https://doi.org/10.1016/j.indcrop.2008.11.002

Mahdian F, Mahboub M, Rahimi E, Shad MM. Chemical composition, antimicrobial and antioxidant activities of Echinophoro platylobo essential oil. Infect. 2017;21(3):171-86. Available from: https://doi.org/10.22354/in.v21i3.675

Natukunda MI, Natukunda K, Kyeyune G, Tusiime SM, Agbemafle I, Bisikwa J. Management strategies for the noxious invasive parthenium weed (Parthenium hysterophorus L.) in Uganda. Afr J Agric Res. 2020;15(1):1-9. Available from: https://doi.org/10.5897/ AJAR2019.14569

Ni G, Li F, Chen B, Song L, Peng S. Allelopathic plants 21: Mikonia microntho H.B.K. Allelopathy J. 2007;19(2):287-95

Pirbalouti AG, Izadi A, Poor FM, Hamedi B. Chemical composition, antioxidant and antibacterial activities of essential oils from Ferulago on- gulate. Pharm Biol. 2016;54(11):2515-20. Available from: https://doi.org /10.3109/13880209.2016.1162816

Pohl CH, Kock JLF, Thibane VS. Antifungal free fatty acids: a review. In: Méndez-Vilas A, editor. Science against microbial pathogens: communicating current research and technological advances. Badajoz: Formatex; 2011. p. 61-71.

Ray P, Gour H.Integrated management of Porthenium hysterophorus L.(Asteraceae): a weed of worldwide significance. Ind J Mycol PI Path. 2012;5(1):605-32.

Sands DC, Pilgeram LA. Methods for selecting hypervirulent biocontrol agents of weeds: why and how. Pest Manag Sci. 2009;65(5):581-7. Available from: https://doi.org/10.1002/ps.1739

Shirani M, Samimi A, Kalantari H, Madani M, Kord AZ. Chemical composition and antifungal effect of hydroalcoholic extract of Allium tripedale (Tvautv.) against Candida species. Curr Med Mycol. 2017;3(1):6-12. Available from: https://doi.org/10.18869/acadpub.cmm.3.1.6

Steel RGD, Torrie JH. Principles and procedures of statistics: a biometrical approach. 2nd ed. New York: McGraw Hill; 1980.

Sureshkumar P, Senthilraja P, Kalavathy S. In-Silico docking analysis of Colotropis gigonteo (L.) R. Br. derived compound against anti-cervical cancer activity. World Res J Comput-Aided Drug Des. 2012;1(1):9-12.

Thomma BPHJ. Alternaria spp.: from general saprophyte to specific parasite. Mol Plant Pathol. 2003;4(4):225-36. Available from: https://doi.org/10.1046/j.1364-3703.2003.00173.x

Tsuge T, Harimoto $Y$, Akimitsu K, Ohtani K, Kodama M, Akagi $Y$ et al. Host-selective toxins produced by the plant pathogenic fungus Alternario alternato. FEMS Microbiol Rev. 2013;37(1):44-66. Available from: https://doi.org/10.1111/j.1574-6976.2012.00350.x

Vukovic N, Milosevic T, Sukdolak S, Solujic S. Antimicrobial activities of essential oil and methanol extract of Teucrium montonum. Evid Based Complement Alternat Med. 2007;4(Suppl.1):17-20. Available from: https://doi.org/10.1093/ecam/nem108

Zhang LH, Kang ZH, Jiao X, Xu WC, Zhang LJ. Isolation and structural indentification of herbicidal toxin fractions produced by Pythium aphanidermatum. Agric Sci China. 2010;9(7):995-1000. Available from: https://doi.org/10.1016/S1671-2927(09)60182-6

Zonno MC, Vurro M, Lucretti S, Andolfi A, Perrone C, Evidente A. Phyllostictine A, a potential natural herbicide produced by Phyllosticto cirsii: in vitro production and toxicity. Plant Sci. 2008;175(6):818-25. Available from: https://doi.org/10.1016/j.plantsci.2008.08.003 